\title{
Recovery and Resolution Regimes in the Banking Union
}

\author{
Mejra Festić ${ }^{\text {, Anita Peša }}{ }^{2}$, Marko Lukavac $^{2 *}$ \\ ${ }^{1}$ Faculty of Business and Economics, University of Maribor, Maribor, Slovenia \\ ${ }^{2}$ Department of Economics, University of Zadar, Zadar, Croatia \\ Email: mejra.festic@um.si, apesa@unizd.hr, ^mlukavac@unizd.hr
}

How to cite this paper: Festić, M., Peša, A., \& Lukavac, M. (2021). Recovery and Resolution Regimes in the Banking Union. Modern Economy, 12, 174-193. https://doi.org/10.4236/me.2021.121009

Received: December 5, 2020

Accepted: January 26, 2021

Published: January 29, 2021

Copyright (C) 2021 by author(s) and Scientific Research Publishing Inc. This work is licensed under the Creative Commons Attribution International License (CC BY 4.0).

http://creativecommons.org/licenses/by/4.0/ (c) (i) Open Access

\begin{abstract}
This paper explores the implications of European Union (EU) legal regulations on approaches to tackling crisis situations in the financial sector. It explains the role and mechanisms of $\mathrm{EU}$ institutions in the process of monitoring and recovery of strategically important financial entities inside banking union at the EU level as well as of central bank members of the countries of the banking union. The purpose of the paper is to examine the compliance of EU regulations with national legislation in order to achieve preventive conditions of possible future crises and to protect national economies and the economy of the entire EU in context of the spillover effect and risks arising from the need of banks recovery due to realized losses of the same. The results evince the implementation of EU directives in the national legislation comprehensively, but practice demonstrated that the implementation of the same ones resulted in additional problems that require further EU institutions action and, in addition, different interpretations, i.e. evaluation of directives such as so-called "public interest", results in discrepancy of approaches in managing open crisis situations.
\end{abstract}

\section{Keywords}

Recovery, Resolution, Banking Union, Bail-In

\section{Introduction}

Contribution of this paper is determined from describing the banking union's functioning model in the context of supervision, resolution and recovery of financial institutions, which aims to revise the validity of further intervention by the European Commission, and especially to protect the taxpayers and EU citizens, creditors in financial institution insolvency proceedings and to ensure the 
transparency of its implementation.

The banking union at EU level is the answer to the latest financial crisis and the fear of emerging as a result of the high indebtedness of some member states, among which Italy is the most recent. In the context of this paper, it is important to analyze Single Supervisory Mechanism (SSM), a Single Resolution Mechanism (SRM) based on a Single Resolution Fund (SRF) operated by the Single Resolution Board (SRB) and the European Deposit Insurance Scheme (EDIS) also managed by the Single Resolution Board (SRB). The first is aimed at monitoring approximately 130 of the largest banks and investment companies in the Eurozone (GSII) that meet the following criteria:

- the total asset value exceeds EUR 30 billion;

- the ratio between assets and GDP of a member state exceeds $20 \%$ unless the total value is lower of EUR 5 billion;

- when the national competent authority considers the institution to be significant and the ECB confirms it as significant.

The second is aimed at raising funds from banks' own resources and accumulating into a single fund, with the aim of avoiding spending money on taxpayers' money to repair banks when their survival is threatened and vital to the country's economy. Thus, relatively small target of the SRF accumulating funds ( $1 \%$ of the value of all covered deposits in participating Member States) is the result of EU legislation, namely the BRRD (Bank Resolution and Recovery Directive) established tough rules on the "bail in" of creditors, before a bank is eligible to receive financial support from the SRF. The third assumes the banks' contribution to their own risk as a single fund rather than a payment to national deposit insurance schemes with the aim of raising funds in the amount of $0.8 \%$ of the amount of deposits in the Eurozone and other affiliated member states to banking union. EX-ante, there was a clear intention to make the key pillars of the banking union in the Eurozone self-financing, obviating the need for financial support from the budgets of participating member states (Belke \& Gros, 2016a: p. 24).

It is noteworthy that not all members of the EU are at the same time members of the Eurozone. The main potential uses of the banking union from the perspective of member states outside the Eurozone are harmonized banking regulation and convergence of supervisory practice, improved regulatory framework, common fiscal protection mechanism, lower costs of adjusting with bank regulation, the active monitoring of European Central Bank (ECB) and the possibility of intervention, and strengthening of banks' cross-border barriers financial stability in the context of eliminating negative backlinks between banks and the state (Šošić, 2016).

On the other hand, the basic shortcoming of accession to the banking union of a country outside the Eurozone is unequal treatment regarding the issue of a common protection mechanism. While for the Eurozone members exists a European Stabilization Mechanism (ESM) from which funds banks can be recapita- 
lized and which serves as a common protection mechanism, member states of banking union outside the Eurozone cannot rely on its use (Vujčić 2016). According Belke, Dobranska, Grosand, \& Smaga (2016: p. 23), due to treaty constraints, non-euro countries participating in the banking union will not be on equal footing with euro members area. Their analyses suggest non-euro countries to join banking union upon the euro adoption, as opt-ins are also excluded from the access to credible backstops.

At the constant initiative of the European Banking Authority (EBA) from 2013., in order to protect the banking system from resistance, in response to a Liikanen report aimed at structural reform with regard to systemic risks arising from the "too-big-to-save", "too-big-to-fail" extreme and "to-complex-to-resolve", the 2014, proposal for a resolution scheme provides an alternative to compulsory liquidation, known for the lengthy process that limits creditors' access to funds. An alternative to compulsory liquidation, which is judged to be undesirable, appears as a process in which banking supervisors actively participate in evaluating recovery plans.

Despite the principle of subsidiarity, in international bank restructuring and resolution situations, the resolution authority is allowed to decide, together with the competent national authorities, on the separation of high-risk trading activities in a comprehensive resolution plan. This will create preconditions for the sustainability of the restructuring rather than liquidation. Process of choosing to avoid liquidation confirms the commitment of a number of countries, which unifies the approach to macroeconomic strategy formation despite the autonomy of economic policies of members. Confirmation can be fined in the Final report of European Commission (2019) named Study on the differences between bank insolvency laws and on their potential harmonisation dated to November 2019.

\section{Literature Review and Methodology}

Schoenmaker \& Gros (2014) have contributed to the development of the banking union as it exists today, emphasizing the importance of cumulating deposit insurance funds in a single fund as one of the pillars of the banking union, pointing to the need to establish a European Deposit Insurance and Resolution Authority (EDIRA) as an independent body from the European Central Bank (ECB). In addition, Schoenmaker \& Veron (2016) have reviewed the issue of the functioning of the banking union, i.e. banking supervision in the first eighteen months since the establishment of new supervisory practices, and also raise the question of the separation of the role of supervision and the resolution of financial institutions from central banks as holders of monetary authority. Arons (2014), World Bank Group (WBG) (2017) and Festić (2019) have addressed the topic of banking supervision, rehabilitation and recovery, and also consider possible mechanisms used within the banking union and EU legislation. Shoenmaker, Veron, \& Darvas (2016) reassessed the feasibility of applying EU practic- 
es, primarily in the context of legislative alignment across countries on the Asian continent, whereas Belke \& Gros (2016b) compared the significant integration of the US banking sector with still predominantly national banking systems in the Eurozone countries, the Federal Reserve System (FED) and the ECB itself, and conclude that greater financial integration and self-sustainability of the financial system increase the ability to absorb losses within, reducing the need for fiscal integration in the banking union. Lastly, researchers from the British Institute of International and Comparative Law (2018) and the Association for Financial Markets in Europe (2018) examine the impact of current Brexit on cross-border cooperation in the areas of banking supervision, rehabilitation and recovery, and the conduct of insolvency proceedings.

This paper elaborates procedures of the emergence, prevention and resolution of the consequences of financial crisis situations in the EU states members of the banking union, among the stakeholders of financial business processes.

The paper raises two basic questions:

1) Should the further strengthening of the legal framework and the protection of the European Union's economic space be pursued through alignment of national insolvency legislation in order to minimize the spillover effect in the financial sector and standardize the financial institutions operating patterns at the macro-level and actions of regulatory and legislative authorities at the micro level, i.e. ensuring transparency of insolvency proceedings and preventing misuse of the so-called "concept of public interest" in crisis situations?

2) Can the behaviour of depositors be changed due to the abandonment of the bail-out concept and the use of the bail-in instrument?

The correct approach of the author to the problem and the correct selection of practical examples was confirmed by the latest European Commission Report on the application and review of Directive 2014/59/EU (BRRD) and Regulation 806/2014 (the Single Resolution Mechanism Regulation), providing an overview of the activities of the EC, the directives and regulations adopted, the success of their implementation, quoting examples of the implementation of directives and regulations in practice, which have been elaborated by the authors in detail, and highlighting the problems identified (EUR-Lex, 2019: p. 1-14). However, the short time that has elapsed since the full implementation of directives and regulations and the stability of the financial sector in recent years, as well as positive economic developments in EU countries, have initiated a theoretical approach to the problem and a rethinking of the effects of focusing on a smaller number, above all qualitatively processed, practical examples.

This work is compiled of sections beginning with the introduction, continuing with literature review and methodology, section recovery, resolution regimes and failure procedures where the theme is based on theory and the section functioning of the banking union and mechanisms in practice which represents the practical part based on an overview of the experience in applying EU directives and sets ahead the challenges of implementation from general approach to indi- 
vidual task. In sections discussion and conclusions there are given answers to the main questions defined in this paper and there are detected problems that can be object of future researches.

\section{Recovery, Resolution Regimes and Failure Procedures}

Preventive actions include recovery and resolution measures aimed at crisis management. These measures take place on two levels, the first preventive activity contained in the recovery involves measures within the financial institution itself supervised by competent authority in context of ECB/SSM, while the resolution measure, contains activities for harm reduction in the social community. Therefore it includes the authority of SRB. Pursuant to the above levels, the implementing bodies are appointed and the recovery plan is implemented by the bodies of the institution of the bank itself, while the resolution plan establishes cooperation with national financial bodies, with responsibility sharing among members of the central bank, supervisors and head of government. The goal of recovery engagement is to reduce the likelihood of bank liquidation while establishing sound management of a financial institution, which includes planning for the acquisition of capital and maintaining liquidity. The goal of resolution engagement is to defend the national system, which presupposes the collection of sufficient information based on analyses for a jointly effective decision-making process. Problem identification is performed using standard qualitative and quantitative criteria based on EBA and internal criteria of a financial institution (EBA, 2013), (EUR-Lex, 2011).

The purpose of recovery plan is to assure business continuity. Recovery measure is preventive activity to avoid resolution. According to this early intervention, EBA requires that recovery plan includes scenarios for a systemic-wide event, for idiosyncratic event and a combination of system-wide and idiosyncratic events (Festić, 2019):

"Considering systemic wide events, an analysis must include the shortfall from public bonds impact on capital and liquidity, the business model impact on profitability and its effect on payment systems etc.

Considering idiosyncratic events, could be a severe write-off in a certain asset class, the leveraged buyout market effect."

The main part of a recovery plan is to anticipate and analyze early disproportionate indicators. Preventive action involves negotiating with relevant stakeholders to avoid liquidation. The activities focus on the categories of organizational structure, capital and the structure of funding sources. There is an option of reaching a joint decision for the sustainable result when competent authority and EBA have disagreement in matter under their jurisdiction.

According to Claessens \& Kodres (2014), a system approach is all the more necessary as modern financial intermediation processes add newer elements that do not always fit into the traditional, silo based ways of formulating microprudential, bank- or market-based regulations and conducting institution-based or 
market-specific supervision. That means more holistic reform approaches including the interactions between and across participants, markets, institutions and jurisdictions, and across types of risks (e.g., market, credit, liquidity, and operational), within and across jurisdictions.

The resolution does not unconditionally result in the liquidation of banks but leaves the possibility of doing business on a new basis of subscription capital by shareholders and creditors. Participants appear as aggrieved parties, but not only as losers in activities that involve the sale of property entered in by creditors. Burden restructuring leaves a relationship of participation in which both shareholders and creditors participate in the loss. According to Festić (2019) the cascade of the liabilities in order of loss bearing:

- common equity Tier 1 ,

- additional Tier 1 and Tier 2 instruments,

- claims from senior executives,

- other subordinated creditor claims,

- unsecured non-preferred claims.

With such changes in the power relations, financial institution realized the possibilities of existence. Avoidance of remediation has sponsored a negative trend in the perception of banking institutions that are avoiding and emerging bank insolvencies in the future. Because there are no simple models and tools to respond to published financial markets and institutions that already serve high social costs, resorting to compromise development is not unknown.

In the resolution process, shareholders lose capital and creditors value of their claims, with the priority being the pay out on the creditor's side. The loss bearing is done according to BRRD principles while the traditional distribution after liquidation of assets is applied after the dissolution of the entity (Schelo, 2015: p. 81). For the purpose of capital repayment, annual losses are covered by holders of subordinated debt notes to prevent the institution from collapsing. It also seeks to reduce liabilities by converting debt into equity or by transferring debt to a bridge bank, also improving liquidity and reducing the amount of resolution funds needed.

Recovery and resolution procedures are aimed at better positioning creditors than would be the outcome of the liquidation. That structure is covered by national legislation, which undertakes to assess in detail the position of participants in recovery and resolution procedures. According to Hellwig (2018) the payouts that investors get in an insolvency procedure are only found out ex post, when the proceeds from the disposal of the debtor's assets are known and distributed to the different investors. In contrast, the decisions of resolution authorities are taken ex ante, at a time when the proceeds from disposing of the debtor's assets are not yet known. It is preferable to economically calculate the value in relation to the market value concept, especially in the conditions of depressed market when the price drop is generated, and define the procedures for protection of value before the sale process begins (Hellwig, 2017). 
The procedures guarantee the equality of creditors in the context of using individual strength to impact amount of the haircuts. Contrary, under a former regime in Germany, the authorities had the authority to decide on preferred creditors, dividing them into those who remained in a failing institution or had been relocated to a transitional bridge bank.

The deposit protection scheme is defined up to EUR 100,000 (EUR-Lex, 2014a Article 2, Directive 2014/49/EU). By Article 44 of the same Directive, covered deposits are not included in the bail-in mechanism. Directive places uncovered deposits of natural persons and SMEs (micro, small, medium sized enterprises), whose assets exceed EUR 100,000 in higher priority ranking compared to other creditors. The hypothetical quota in an insolvency process will be staple, if these deposits are granted priority in insolvency. These deposits might get the sum of $100 \%$ in an insolvency procedure (Festić, 2019).

Incorporating burden sharing arrangements between countries enables burden sharing on an institution by institution basis, but there are problems arising from the incompatibility of the laws governing cross-border bank insolvencies. (Avgouleas, Goodhart, \& Schonmaker, 2013).

The principle "too big to fail" explains the situation of systemically important financial institutions and exposes the questions of introducing a special insolvency law for banks in which competent authority has the power to undertake a systematic review of certain other activities, like market-making conditions, investment in/sponsoring of securitization and trading of certain derivatives (Randell, 2015).

The institution infringes the requirements for continuing authorisation in a way that would justify the withdrawal of the authorisation by the competent authority because institution is likely to incur losses. Balance sheet insolvency and over-indebtedness are verified by measuring the value of assets versus the value of liabilities. Also, the value of assets can be estimated by liquidation value or going concern value. The first, the liquidation method, prejudices the sale of assets with a view to a final settlement, while going concern value projects the value based on the continuation of business, i.e. through the future possible time of settlement and sale of assets. Considering that the bank's regulatory capital is determined according to the riskiness of the bank's assets, and the indebtedness assessment involves an analysis of all assets and liabilities, the question arises to determine the indebtedness threshold not defined by the BRRD.

Many corporate insolvency statutes and some insolvency laws refer also to the cash-flow insolvency as illiquidity. In some countries there is known the concept of temporary illiquidity (temporary funding gap of $10 \%$ and even more is tolerated in short term).

Central banks achieve to increased liquidity through emergency liquidity funds if financial institutions have sufficient securities. As the cash gap also arises as a result of the time disproportionate maturity of the liabilities and the time required to sell the assets, the assumption that the bank will not be able to mon- 
itor current outflows within the set deadlines generates an impending illiquidity (Article 32, BRRD).

Bail-in tool aiming a recapitalisation will always be accompanied with a business restructuring plan, which should verify that the institution will become viable after the application of this resolution too. In order to restore financial stability and long-term sustainability, a bail in tool is also used in the context of business reorganization. According to Schelo (2015) and Article 44 (BRRD), liabilities that are protected from bail-in are the following items:

- covered deposits under the amount of EUR 100.000,

- secured liabilities and covered bonds,

- liabilities held by the institution as a trustee,

- liabilities to other banks and investment firms with an original maturity off less than seven days,

- liabilities with remaining maturity of less than seven days,

- liabilities to employee,

- client money and fiduciary assets,

- liabilities to commercial or trade creditors if they relate to activities that are critical to daily functioning of the business

- preferred liabilities owed by tax or social security authorities.

Insofar the value of the security covers its liability, covered bonds and secured liabilities are "safe" from bail-in tool. According to Festić (2019) above the value of the pool covering of bonds and above the values of the securities, the bail-in is possible.

The possibility of improving liquidity is also provided in cases where shareholders and other creditors absorb at least $20 \%$ of the risk-weighted assets through a bail-in tool. The financing can be drawn from ex-ante contributions made to national resolution funds. The cumulative amount of contributions is at least 3\% of the covered deposits of all the credit institution in a relevant member state.

In order to minimise the amount of "bail-in-able" liabilities and reduce the exposure of investors, the Minimum Requirements for Own Funds and Eligible Liabilities (MREL) was introduced and circumvention of the purpose of "bail-in" toll was avoided. MREL is expressed as a percentage based on the sum of own funds plus total liabilities divided by the sum of the total liabilities plus own funds (the resolution authorities will assess the applicable MREL amount in parallel to reviewing resolution plan). MREL is assessed on a case-by-case basis. The liabilities with the remaining maturity of at least one year can only be counted for MREL. As deposits, secured liabilities, any short-term liabilities are excluded, basically senior bonds would count against MREL.

Total Loss Absorbing Capacity (TLAC) (that should be subordinated to senior debt) is supposed to have very similar role as MREL i.e. to oblige institutions to create buffers for bail-in. This purpose could be reached contractually or by setting holding structure (Bank for International Settlements, 2016), (Huertas, 2011). 
According to Repullo \& Saurina (2012) the conditions for contractual "bail-in" instruments have to be fulfilled in a way of binding subordinated agreement, which cannot be repaid until other eligible liabilities outstanding have been settled at the time. Also, before other eligible liabilities are written down or converted by decision of resolution authority, the instrument must be written down or converted on the contractual basis to the needed extent required.

Following Schelo (2015), resolution authority has the power to transfer to a bridge bank: 1) shares and other instruments of ownership issued by one or more institutions under resolution; 2) any assets, rights or liabilities of one or more institutions under resolution; which means the shares of the institution, assets and liabilities of the institution which is likely to fail or is failing can be transferred to a bridge bank. Comparing the bail in tool with the bridge bank tool, it follows that assets transferred to the bridge bank form the basis for a continuation of the bank's business under a different ownership structure. On the other hand, assets left in the original/previous institution are most often assets subject to the burden of liquidation (Merler, 2017). It is a value that would be the subject of a bail-in tool if it were used instead of transferring healthy value to the bridge bank (Micossi, Bruzzoneand, \& Cassella, 2014). Compiling with the no creditor worse-off principle, the creditors and shareholders which stay behind in the failing institution should not receive less than they would have receive in the case of ordinary insolvency of the institution, too (Muller, 2015).

According to Festić (2015) the BRRD requires that:

- any security attached to a transferred liability is transferred together,

- netting rights may not be changed when liabilities tied to netting agreement with counter claims are transferred,

- there is a protection for structured finance arrangements,

- certain trading clearing and settlement systems shall be protected.

Resolution authorities always apply the asset separation tool together with another resolution tool (Petitjean, 2013). The intention is to transfer assets and liabilities to a Asset Management Vehicle which have suffered losses with a view to maximising the value in order to minimise the losses by eventual sale or orderly wind-down.

\section{Functioning of the Banking Union and Mechanisms in Practice}

Bank Recovery and Resolution Directive (BRRD), (EUR-Lex, 2014b 2014/59/EU), meaning the end of using concept bail-out, according to which rescuing banks could initiate a huge amount of using public funds, and introduces concept bail-in according to which the costs of recovering of the banks should be realised by unsecured creditors and special funds created by the successively payments of the banks. Because of the process, can be expected changes in behaving of deponents and in a business model of the banks in the future (Vujčić, 2016).

For the more successful implementation of the bail-in concept, banks are ob- 
liged to meet the MREL, and additionally, under previously defined conditions, a Global Systemically Important Institution (GSII) is required to have sufficient minimum obligations with high capacity to cover losses i.e. a sufficient amount of liability that can apply the bail-in concept.

According to the latest status of the BRRD Directive 2014/59/EU, the same is completely incorporated in the legislation of all EU countries, but the transfer of provisions to national legislation has not been involved easily. Just before the deadline for the implementation of the Directive, on $22^{\text {nd }}$ October 2015, the Commission found that the Czech Republic, Luxembourg, the Netherlands, Poland, Romania and Sweden failed to import into their national legislation the directive and were consequently notified to the Court of Justice of the European Union. The same applies to Directive 2014/49/EU, which refers to the so-called "the third pillar" on which the banking union is based, the deposit insurance system. On $10^{\text {th }}$ December 2015, the Commission concluded that Belgium, Cyprus, Estonia, Greece, Italy, Luxembourg, Poland, Romania, Slovenia and Sweden did not fully implement the Directive on deposit guarantee schemes in their national legislation (Dvornik \& Jurica, 2016).

The main disadvantage deriving from Directive 2014/59/EU was to apply the bail-in concept, i.e. the fact that national insolvency laws between member states differed considerably in the rules on insolvency hierarchy of unsecured senior debt. This would make it more difficult to apply the bail-in concept for cross-border institutions and distort competition in the internal market because of the costs that institutions must meet in the subordination and cost requirements, i.e. the risk that investors have when purchasing debt instruments issued by institutions could significantly differ within the Union. The solution above derives, set out from Directive 2017/2399/EU amending Directive 2014/59/EU (EUR-Lex, 2017) in regard of the ranking of unsecured debt instruments at the insolvency level. The Directive requires the establishment of a new category of non-preferred senior class of debt instruments, which should have a higher order of priority than the regulatory capital instruments and any subordinated liabilities that do not qualify of the own funds. That allows institutions to use, for purpose of their own financing or for any other operational purpose, the deploy of even more competitive regular superior debt instruments, and to issue debt instruments within the new category of non-preferred superior debt for the purposes of obtaining financial resources and meeting the requirements set out in the Total Loss-absorbing Capacity (TLAC) standard.

Additional issues related to the processed topic were raised by themselves as needed, for example, by banks Banco Popular Español, Banca Popolare di Vicenza, Veneto Banca and Monte dei Paschi di Siena on the other side, and Jadranska Banka on the third side. Two groups of questions that arise from the above-mentioned examples are:

1) Is it possible to define the specific significance of the financial institution and the public interest to preserve it as well? 
2) What is the usual insolvency procedure, how different it is from member to member and is it possible to harmonize it at EU level?

Slovenia fully implemented bail-in tool in 2013 according to the state aid rules after the $1^{\text {st }}$ of August 2013. The state aid rules become stringent after the $1^{\text {st }}$ of August 2013. Before 2011 it was enough only to apply for the state aid and to enclose the plan of recovery of banks. After 2011 the state aid rules become stringent and it was necessary to issue subordinated instruments before applying to the state aid. And in 2013 the rules become more stringent. Slovenia was the first state in Eurozone applying bail-in instruments on the case of six state owned banks.

It is considered that the banking union has not yet fully realized because of the uncertainty of the term of public interest and the not harmonized insolvency proceedings among the members. This problem is dealt with by the Commission, which by the end of 2018 committed to evaluate the necessary actions in the context of the harmonization of insolvency law on the basis of a detailed comparison of the same among the members (Deslande \& Magnus, 2018). The author's opinion is that a big problem is the so-called "double criteria" because at present the applicable regulations of a financial institution of the same size and similar characteristics, in different member states but even in the same country, due to possible different interpretations of the public interest, they can undergo various mechanisms of recovery and resolution. Kleftouri (2017: p. 17) noted a rather broad definition, that is, a vague definition of "financial stability" notion within the BRRD, which also raises the additional question of whether a bank with a small balance sheet size or limited interconnectedness could have a significant adverse effect on domestic financial stability if it failed or is it only larger banks in size or more interconnected banks that could have an adverse effect on financial stability. Also, the BRRD does not include a specific numerical indicator of critical undercapitalization, that serves as a clear quantitative trigger. In any case, the early trigger raises further concerns regarding the treatment of liability holders as well as equity holders (Hadjiemmanuil, 2015: p. 19). Certainly, the issue of transparency of the insolvency process and the so-called special insolvency processes is also raised, which management requires underwriting of a special legislation.

Recovery of the Banca Popular as the sixth largest bank in Spain was declared as a public interest, i.e. the Single Resolution Board (SRB) submitted to the Commission a recovery program for Banco Popular Español, which was confirmed by the Commission by Decision 2017/1246/EU. In the recovery procedure, the funds of the Single Resolution Fund (SRF) were not used since after the application of a bail-in mechanism i.e. write-down capital and AT1 securities, and additional conversion of AT2 securities, mostly subordinated debt, into new capital, the bank was sold to Banco Santander for 1 euro after which the new owner recapitalized the bank with an additional 7 billion euros (KPMG, 2017). The recovery of Banco Popular has been extremely successfully implemented 
from the point of view of the fact that in the process, the owners of the superior debt and depositors did not bear any losses, nor did public funds and guarantees be used (Dagong Europe, 2017). The second case is the refusing of recovering from the SRF and using its funds for purpose of recovery of the BancaPopolare di Vicenza, Veneto Banca and Monte deiPaschi di Siena companies, in accordance with the estimation given by the SRB that the same banks are not systemically important for the financial stability of Italy and even the Union. Table 1 is following with key financial indicators based on which the SRB has made appropriate decisions.

However, despite the decision of the SRB and in line with the BRRD, Italy did not allow market-based liquidation of its banks, but in the concrete case recovered banks by public funds and handed them over to the Intesa Sanpaolo Group for 1 euro with additional state guarantees. Italy referred to Article 32 (4.d) of the BRRD, which does not exclude the possibility of intervention by the State if it is justified by the criterion of economic impact and financial stability. The bank liquidation process included a write-down of existing equity and part of the subordinated debt, leaving banks to another banking group for a symbolic fee of EUR 1, paying the new owner EUR 4.8 billion, or EUR 3.5 billion so that a new acquisition would not harm liquidity and the stability of the new owner and EUR 1.3 billion to cover the cost of a new owner in the context of closure of branch offices and business migration. In addition, the state has issued Intesa Sanpaolo as the new owner of the recovered banks EUR 12 billion in additional state guarantees to offset potential losses (Merler, 2017).

Table 2 summarizes the outcomes and mechanisms used in the recovery processes of Banco Popular Español, Banca Popolare di Vicenza, Veneto Banca and Monte deiPaschi di Siena.

Table 1. Key financial highlights and rations for the case study banks.

\begin{tabular}{cccc}
\hline Key Financials YE-2016 (EUR Bn) & $\begin{array}{c}\text { Banco Popular } \\
\text { Espanol SA }\end{array}$ & $\begin{array}{c}\text { Banca Popolare di } \\
\text { Vicenza SpA }\end{array}$ & $\begin{array}{c}\text { Veneto } \\
\text { Banca SpA }\end{array}$ \\
\hline Total Assets & 147.9 & 34.4 & 28.0 \\
Total Gross Loans & 104.3 & 27.3 & 19.2 \\
Total Deposits & 82.8 & 14.3 & 20.0 \\
Senior Debt & 15.0 & 3.4 & 6.3 \\
Subordinated Debt & 2.0 & 0.645 & 0.624 \\
Common Equity Tier 1 & 10.8 & 1.6 & 1.2 \\
Key Ratios & & & \\
Gross Non-Performing Loans & $18.8 \%$ & $35.8 \%$ & $38.5 \%$ \\
Net Non-Performing Loans & $9.9 \%$ & $22.8 \%$ & $26.3 \%$ \\
Common Equity Tier 1 Ratio & $12.1 \%$ & $7.5 \%$ & $6.4 \%$ \\
Loans Market Share & $7.8 \%$ & $1.5 \%$ & $1.0 \%$ \\
Deposits Market Share & $6.1 \%$ & $1.0 \%$ & $1.0 \%$
\end{tabular}

Author's work according to the Banks' annual reports from Dagong Europe (2017). 
Table 2. Summary of actions and outcomes.

\begin{tabular}{|c|c|c|c|c|}
\hline & & $\begin{array}{c}\text { Banco Popular } \\
\text { Espanol }\end{array}$ & $\begin{array}{c}\text { Banca Popolare di } \\
\text { Vicenza and } \\
\text { Veneto Banca }\end{array}$ & $\begin{array}{c}\text { Monte dei Paschi di } \\
\text { Siena }\end{array}$ \\
\hline \multicolumn{5}{|c|}{ Bail-in } \\
\hline \multirow{2}{*}{$\begin{array}{l}\text { BRRD } \\
\text { resolution } \\
\text { tool }\end{array}$} & Sale of Assets & Sale of entire bank & $\begin{array}{l}\text { But liquidation not } \\
\text { resolution }\end{array}$ & $\begin{array}{l}\text { But as condition for } \\
\text { State Aid, not } \\
\text { resolution }\end{array}$ \\
\hline & $\begin{array}{l}\text { Asset Management } \\
\text { Company }\end{array}$ & & $\begin{array}{l}\text { But liquidation not } \\
\text { resolution }\end{array}$ & \\
\hline $\begin{array}{c}\text { BRRD } \\
\text { alternative }\end{array}$ & $\begin{array}{l}\text { Precautionary } \\
\text { recapitalisation }\end{array}$ & & & \\
\hline \multicolumn{5}{|c|}{ Liquidation } \\
\hline & $r$ support & & & \\
\hline
\end{tabular}

Author's work according to the KPMG (2017) Public.

The Jadranskabanka (Croatia) is an example of a small private bank with a total asset value of about EUR 250 million. The bank with a market share of less than $0.5 \%$ in the Republic of Croatia was recovered with the funds of the National Recovery Fund amounting to approximately EUR 70 million, but the same decision was justified after the analysis of the deposit, which indicated that almost $90 \%$ of the deposit was covered, owned by private deponents up to the amount of 100 thousand EUR, i.e. the cost of bank liquidation for the State Deposit Insurance and Recovery Agency would be almost three times higher than the recovery. It should be noted that recovery of the Jadranskabanka is the first case of a bank recapitalization in the Republic of Croatia that was not done "across the back" by taxpayers but exclusively by shareholders of banks, creditors and other credit institutions in the Republic of Croatia through the National Recovery Fund (HPB, 2018).

The bank recovery was carried out according to the so-called "Small Banks Recovery Scheme in the Republic of Croatia", approved by the Commission in 2016, which included the management of a recovery procedure and the application of a bail-in mechanism to the value of share capital and other unsecured bank liabilities for the purpose of converting debt into a new capital and final sale of the bank (SADIBR, 2016).

The Republic of Croatia has fully implemented the EU directives by adopting a supplement to the Credit Institutions Act and the Credit Institutions and Investment Companies Recovery Act in 2015. 
The Credit Institutions Act provides a detailed explanation of the competence of the Croatian National Bank in the context of supervision and the procedures for bank liquidation and bankruptcy. Article 154 of the same law defines the obligation of banks to prepare a recovery plan, and Article 101 of the CNB has enabled the adoption of subordinate legal acts specifying more precisely the requirements related to the bank management system (NN, 2015a). The Credit Institutions and Investment Companies Recovery Act explained remedies models in accordance with Directive 2014/59/EU. Articles 65-71 define the main points for the implementation of the bail-in instrument (term, instruments that may be the subject of conversion and hierarchy, the expropriation of ownership shares and the volume) that have been applied during the recovery of the Jadranskabanka (NN, 2015b). Article 57 of the same law defines a sale of business instrument that is also applied in the case of the Jadranskabanka, but after the implementation of the bail-in instrument.

However, the entire recovery and resolution process lasted long since 2015, when the process was opened until 2018, when the bank was acquitted by the Croatian Post Bank (HPB) and recapitalized with an amount of about EUR 15 million (Klepo, 2018). The example of the Jadranskabanka is the first example in the Republic of Croatia to apply a bail-in mechanism to the uncovered deposits, which provoked disapproval of part of the private deponents and primarily legal entities and public bodies whose liquid cash funds have been converted into the bank's equity holdings. However, the overall process was ultimately carried out transparently and in compliance with the legal regulations in line with the directives of the European Union, and in this case the basic rule was satisfied that creditors cannot suffer any greater losses in the so-called "special insolvency process" in relation to the regular.

\section{Discussion}

Although, the first opinion of the intention of the EU Commission presented in this paper is appropriate, it is not yet clear how the regulation will manifest on banking activity in the medium term. The banking system should certainly be less dependent on the taxpayer's money, but many policymakers fear that bail-ins may undermine confidence in the banking sector and jeopardise financial stability (Philippon \& Salord, 2017).

Based on previous research, and up to the new trends driven by EU regulations, banks were considered to be relatively safe for savings, even in the so-called "crisis times", for the sight deposits (a-vista), too (Gatev, Strahan, \& Shuermann, 2006). In times of crisis, money shifted from uncertain capital markets to banks where savings were considered the safest, and banks reduced the liquidity risk. This fact was supported by the continuous increase in the amount of deposit insurance, raised at EUR 100,000 at EU.

Nevertheless, recent surveys point to the potential problems of banks with liquidity not only in the short, but also in the medium term, inspired by the new 
EU regulation. This is supported by research from Cyprus, where the bail-in instrument was applied during the banking crisis in 2013. On Cyprus, bail-in represented an unexpected shock to resident depositors, and the research showed a strong outflow of resident (and non-resident) deposits in the months after the bail-in implementation (Brown, 2018). Nine months after, respondents were asked how they would allocate a hypothetical sum of EUR 200,000 among different assets (cash, deposit at banks in Cyprus, other investments in Cyprus), if the capital controls were lifted, and the Brown (2018) indicates results were as follows:

"Responses suggested a low level of confidence in banks. One-third of the households would not hold any of their funds in a domestic deposit account, while only 22\% would even hold deposits above the deposit insurance level."

It is concluded that the intention of households was hardly related to how they had been affected by the bail-in. Comparatively, longer-term confidence in banks and money holdings seems to be largely determined by the existence of the "crisis per se" rather than by personal experiences of it (Brown, 2018). Krstić \& Krstić (2016) discuss the possibility of rational choice theory to be a guide for empirical research. The authors of this paper consider that the issue of depositors' behaviour in crisis situations when their deposits are uncovered, requires an approach that should also include ancillary assumptions such as restrictions, preferences and beliefs.

Following the practical examples covered by this section, the authors have identified the need to further strengthen the EU legal framework by aligning national insolvency proceedings in order to minimize the spillover effect in the financial sector and standardize the financial institutions operating patterns at the macro-level and actions of regulatory and legislative authorities at the micro level, i.e. ensuring transparency of insolvency proceedings and preventing misuse of the so-called "concept of public interest" in crisis situations.

Also, following the example from practice and summarizing the sources, the authors have observed that forfeiting the practice of bail-out and applying the bail-in instrument to the amount of unsecured deposits will change the behaviour of depositors in conditions of instability. Until now, banks have been perceived as the safest institutions in crisis situations, and many of them were in the eyes of the public, i.e. depositors, characterized as safe even because of the established paradigm that the concerned institutions were "too big to fail". The depositors' behaviour changing course will also depend on the financial knowledge of the citizens in Eurozone, and it could be verified already at the outbreak of some future crisis, regardless of the fact that most depositors at EU level did not have personal negative experiences with the use of bail-in. In order to avoid or at least timely foresee additional negative shocks to the stability of banks in managing crisis situations, and because of the expected change in depositors' behaviour due to abandonment of the bail-out concept and the use of the bail-in instrument, the research should be directed towards the precise definition of the depo- 
sitors' behaviour changing pattern notion and quantifying the effects of the expected change.

\section{Conclusion}

Following the research materials founded in practical examples, also implementing parts of the EU law, according the experience in domestic countries authors are from and in analyzing this theme from other sources, we can summarise as follows.

There are several tools for the recovering stumbled banking institutions. Writing-down or converting certain liabilities, with the purpose of restoring the capital structure, is allowed by the bail-in tool. Second tool which offers deeper restructuring powers given to the competent resolution authority is named the bridge bank. Similar to the bridge bank tool is the sale of business tool which enables the resolution authority to transfer liabilities, assets and contracts to investors. The asset separation model is always combined with one of the other tools and it is applicable in the cases, when it is necessary to combine a resolution technique with a bad bank scheme by separating certain assets to preserve their value. The write-down instrument has lesser impact on the institution because it affects only equity, additional Tier 1 and Tier 2, while a bail-in tool includes other subordinated debt and senior debt, too. As long as addition resolution tools established in the national legislation are in harmony with the principles of the cross-border resolutions, can be applied.

It is possible to establish additional resolution tools in the national legislation as long as these tools are compatible with the principles and support cross-border group resolution.

The valuation exercise would determine the amount of loss absorption to restore viability of the institution and capital adequacy. The valuation must show how much of own funds and eligible liabilities exist. The decision of whether all eligible liabilities should be taken to loss absorption and which liabilities should be excluded of the bail-in tool according to the BRRD in order to avoid widespread contagion. If the funds are not sufficient, the consideration about financing arrangements follows.

Further, funds could be only drawn from resolution fund, if the $8 \%$ loss absorption has been used by writing down own funds and converting eligible liabilities into equity. If maximum resolution fund amount in the amount of 5\% of own funds and all liabilities should not be sufficient, contributions beyond that are necessary. The resolution authority must decide on the procedure of investing into equity, buying existing instruments, convert in them into equity or even issuing debt instrument. The resolution authority must decide about the loss allocation to different capital structure components.

National financial arrangements contained in BRRD and SRF contained in SRM are tied together. National financing arrangements transfer their resources into the SRF. This transfer occurs with respect to contributions relating to the 
institution supervised by ECB. National funds are responsible for annual contributions from all national banks. National Funds are responsible for collecting ex-ante (regular) and ex-post (extraordinary) contributions from the banking sector in their territory. There is a target in the amount of $1 \%$ of all covered deposits, which should be fulfilled by 2024 . SRF is raising funds through the national fund contributors.

The deposit guarantee schemes are effectively saved only when resolution tools are applied. Covered deposits are not eligible in bail-in scenario, deposits may be transferred in the case of bridge bank scenario and not undergo an insolvency procedure.

The authors suggest that the issues on this topic should be considered first and foremost in the context of so-called institutional reforms aimed at improving the oversight system of the financial market. It becomes evident that the focus should be on responsible bank management, but also depositors, to minimize the negative effects of future crises and contribute to more sustainable growth of EU economies in the medium and long term. Pursuant to theoretical background, practice suggests greater commitment to risk management in order to minimize social losses of all participants in national economies. The continuity of the explained system greatly contributes to the uniformity of EU law implemented at the level of national economies. This is also a confirmation of the aspiration for establishment of a single internal market in the domain of the financial sector.

\section{Conflicts of Interest}

The authors declare no conflicts of interest regarding the publication of this paper.

\section{References}

Arons, T. (2014). Recognition of Debt Restructuring and Resolution Measures under the European Union Regulatory Framework. International Insolvency Review, 23, 57-72. https://doi.org/10.1002/iir.1220

Association for Financial Markets in Europe (2018). Brexit: Recognition of Resolution Actions.

Avgouleas, E., Goodhart, C., \& Schonmaker, D. (2013). Bank Resolution Plans as a Catalyst for a Global Financial Reform. Journal of Financial Stability, 9, 210-218. https://www.sciencedirect.com/science/article/pii/S157230891100060X https://doi.org/10.1016/j.jfs.2011.12.002

Bank for International Settlements (2016). Standard TLAC Holding. Amendments to the Basel III Standard on the Definition of Capital. https://www.bis.org/bcbs/publ/d387.pdf

Belke, A., \& Gros, D. (2016a). Banking Union as a Shock Absorber. Ruhr Economic Papers \#548. https://doi.org/10.2139/ssrn.2618397

Belke, A., \& Gros, D. (2016b). On the Shock-Absorbing Properties of a Banking Union: Europe Compared with the United States. Comparative Economic Studies, 58, 359-386.

Belke, A., Dobranska, A., Gros, D., \& Smaga, P. (2016). (When) Should a Non-Euro Country Join the Banking Union? Ruhr Economic Papers \#613. 
https://www.rwi-essen.de/media/content/pages/publikationen/ruhr-economic-papers/r ep 16 613.pdf https://doi.org/10.1016/j.jeca.2016.07.008

British Institute of International and Comparative Law (2018). How Will Brexit Impact Cross-Border Cooperation in Recovery, Reconstruction and Insolvency Processes? London: Centre for International Governance Innovation.

Brown, M. (2018). Banking Crisis, Bail-Ins and Money Holdings. VOX CERP Policy Portal. https://doi.org/10.2139/ssrn.3102815 https://voxeu.org/article/banking-crisis-bail-ins-and-money-holdings-lessons-cyprus

Claessens, S., \& Kodres, L. (2014). The Regulatory Responses to the Global Financial Crisis: Some Uncomfortable Questions. IMF Working Paper No. 46, Research Department and Institute for Capacity Development.

https://www.imf.org/external/pubs/ft/wp/2014/wp1446.pd

Dagong Europe (2017). Recent Cases of EU Banking Resolution-Liquidation: One Rule Does Not Fit All. Dagonge Europe Credit Rating.

Schoenmaker, D., Veron, N., \& Darvas, Z. (2016). Reform of the European Union Financial Supervisory and Regulatory Architecture and Its Implications for Asia.

Deslande, J., \& Magnus, M. (2018). Further Harmonising EU Insolvency Law from a Banking Resolution Perspective. Economic Governance Support Unit-Directorate General for Internal Policies, 2, 1-9.

Dvornik, I., \& Jurica, D. (2016). Banking Union-Analysing and Future. Journal I'M, 13-20.

EUR-Lex (2011). Directive of the European Parliament and the Council: Establishing a Framework for Recovery and Resolution of Credit Institutions and Investment Firms and Amending Council Directives 77/91/EEC and 82/891/EC, Directives 2001/24/EC, 2004/25/EC, 2005/56/EC, 2007/36/EC and 2011/35/EC and Regulation (EU) No. 1093/2010. COM (2012/280/3).

EUR-Lex (2014a). Deposit Guarantee Schemes. 2014/49/EU.

EUR-Lex (2014b). Recovery and Resolution of Credit Institutions and Investment Firms. 2014/59/EU.

EUR-Lex (2017). Amending Directive 2014/59/EU as Regards the Ranking of Unsecured Debt Instruments in Insolvency Hierarchy. 2017/2399/EU.

EUR-Lex (2019). Report from the Comission to the European Parliament and Council on the Application and Review of Directive 2014/59/EU (Bank Recovery and Resolution Directive) and Regulation 806/2014 (Single Resolution Mechanism Regulation).

European Banking Authority (EBA) (2013). Consultation Paper. Draft Regulatory Technical Standards. On the Assessment of Recovery Plans under the Draft Directive Establishing a Framework for the Recovery and Resolution of Credit Institutions and Investment Firms.

European Commission (EC) (2019). Study on the Differences between Bank Insolvency Laws and on Their Potential Harmonisation. Final Report, European Commission. https://ec.europa.eu/info/sites/info/files/business economy euro/banking and financ e/documents/191106-study-bank-insolvency en.pdf

Festić, M. (2015). Resolution Regimes as the (Sub)pillar of the Banking Union. Bančni Vestnik-The Journal for Money and Banking, 64, 48-52.

https://scholarship.haverford.edu/cgi/viewcontent.cgi? article=1162\&context=economic s facpubs

Festić, M. (2019). International Environment: Recovery and Resolution Regimes as the Pillar of the Banking Union. Our Economy, 65, 30-40. 
https://doi.org/10.2478/ngoe-2019-0009

Gatev, E., Strahan, E., \& Shuermann, T. (2006). Managing Bank Liquidity Risk: How Deposit-Loan Synergies Vary with Market Conditions (pp. 1-38). National Bureau of Economic Research. https://doi.org/10.3386/w12234

Schoenmaker, D., \& Gros, D. (2014). European Deposit Insurance and Resolution in the Banking Union. Journal of Common Market Studies, 52, 529-546.

https://doi.org/10.1111/jcms.12124

Hadjiemmanuil, C. (2015). Bank Stakeholders' Mandatory Contribution to Resolution Financing: Principle and Ambiguities of Bail-In. London: The London School of Economics and Political Science.

Hellwig, M. F. (2017). Carving Out Legacy Assets: A Successful Tool for Successful Restructuring? Brussels: European Parliament, Economic and Monetary Affairs Committee. http://homepage.coll.mpg.de/pdf dat/2017 03online.pdf

Hellwig, M. F. (2018). Valuation Reports in the Context of Banking Resolution: What Are the Challenges? In Depth Analysis Requested by the ECON Committee. European Parliament. Banking Union Scrutiny. Economic Governance Support Unit Directorate General for Internal Policies of the Union.

http://www.europarl.europa.eu/RegData/etudes/IDAN/2018/624417/IPOL IDA\%2820 18\%29624417 EN.pdf

HPB (2018). News: DAB and HPB Sign the Contract of Selling Shares of the Jadranska Banka.

https://www.hpb.hr/novosti/dab-i-hpb-potpisali-ugovor-o-prodaji-dionica-jadranske-b anke

Huertas, T. (2011). The Road to Better Resolution: From Bail-Out to Bail-In. Goethe Universität Frankfurt am Main, Institute for Law and Finance, January. https://www.researchgate.net/publication/254416782 The Road to Better Resolution From BailOut to Bail In

Kleftouri, N. (2017). European Union Bank Resolution Framework: Can the Objective of Financial Stability Ensure Consistency in Resolution Authorities' Decisions? ERA Forum, 18, 263-279. https://doi.org/10.1007/s12027-017-0469-0

Klepo, M. (2018). Defined Conditions of Sale. Jutarnji List (Morning Post). https://novac.jutarnji.hr/aktualno/iako-se-ocekivalo-najmanje-50-milijuna-kn-hpb-za-j adransku-banku-ponudila-12-milijuna-kn/7272948

KPMG (2017). Single Resolution Board: Contrasting Outcomes for Banks, Dealing with Weak or Failing Banks: Are Exceptions Becoming the New Norm (pp. 1-5). KPMG Public Report.

Krstić, B., \& Krstić, M. (2016). Teorija racionalnog izbora i društvena istraživanja. Sociologija, 60, 598-611.

Merler, S. (2017). Bank Liquidation in the European Union: Clarification Needed. Bruegel-Policy Contribution.

Micossi, S., Bruzzone, G., \& Casella, M. (2014). Bail-In Provisions in State Aid and Resolution Procedures: Are They Consistent with Systemic Stability? CEPS Policy Brief No. 318 (May). https://papers.ssrn.com/sol3/papers.cfm?abstract id $=2445900$

Muller, M. W. (2015). Creditor Protection in Bank Resolution: A Case for International Investment Arbitration? Capital Markets Law Journal, 10, 276-294.

https://doi.org/10.1093/cmlj/kmv029

NN Narodne Novine (Official Gazette) (2015a). Credit Institutions Act.

NN Narodne Novine (Official Gazette) (2015b). Credit Institutions and Investment 
Companies Recovery Act.

Petitjean, M. (2013). Bank Failures and Regulation: A Critical Reviews. Journal of Financial Regulation and Compliance, 21, 16-38. https://doi.org/10.1108/13581981311297803

Philippon, T., \& Salord, A. (2017). Bail-Ins and Bank Resolution in Europe. New ICMB/CEPR Report: VoxEU.org.

Randell, C. (2015). Triggers for Bank Resolution. In Too Big to Fail, Brauchen wir Sonderinsolvenzrecht für Banken (pp. 105-126). Frankfurt: Institute for Law and Finance Series.

Repullo, R., \& Saurina, J. (2012). The Countercyclical Capital Buffer of Basel III: A Critical Assessment. In the Crisis after Math: New Regulatory Paradigms. Journal of Financial Intermediation, 22, 45-67.

https://www.researchgate.net/publication/254399043 Cyclical adjustment of capital requirements A simple framework

(SADIBR) State Agency for Deposit Insurance and Bank Rehabilitation (2016). Decision.

Schelo, S. (2015). Bank Recovery and Resolution. International Banking and Finance Law Series, Alphen aan den Rijn: Wolters Kluwer Law and Business.

Schoenmaker, D., \& Véron, N. (2016). European Banking Supervision: The First Eighteen Months. Blueprint XXV, Bruegel.

Šošić, V. (2016). Banking Union Seen from the State Members outside Eurozone. Conference: Banking Union Achievements and Challenges.

Vujčić, B. (2016). Conference Zagreb: Banking Union-Achievements and Challenges. Governor Speech.

World Bank Group (2017). Understanding Bank Recovery and Resolution in the EU: A Guidebook to the BRRD. Vienna: Financial Sector Advisory Center. 